\title{
Amh Polymorphisms and their association with traits indicative of sexual precocity in nelore heifers
}

\author{
Polimorfismos do amh e suas associações com características \\ indicadoras de precocidade sexual em novilhas nelore
}

\author{
Julia Cestari Pierucci ${ }^{*}$; Humberto Tonhati ${ }^{2}$; Lúcia Galvão de Albuquerque ${ }^{2}$; \\ Diercles Francisco Cardoso3; Daniel Jordan de Abreu dos Santos ${ }^{3}$; Ana Cláudia \\ Freitas $^{4}$; Marina Mortati Dias Barbero ${ }^{5}$; Gregório Miguel Ferreira de Camargo ${ }^{6}$; \\ Camila Urbano Braz ${ }^{3}$; Lindsay Unno Gimenes ${ }^{7}$
}

\begin{abstract}
Anti-Müllerian Hormone (AMH) is a protein expressed in the gonads and related to ovarian follicular development. The aim of this study was to investigate the presence of polymorphisms in the $A M H$ gene in a Nelore herd to analyze the genetic constitution of this population and to perform association studies with early pregnancy occurrence (EPO) and age at first calving (AFC). Phenotypic data consisted of verification of early pregnancy and age at first calving of 197 unrelated heifers exposed to the mating season and aged between 15 and 17 months (precocious group) and 24 months (non-precocious group). The "precocious" group consisted of 67 heifers with age at first calving of $26.5 \pm 0.59$ months, and the "non-precocious" group was composed of 130 heifers with age at first calving of $36.4 \pm 0.99$ months. All five exons of the $A M H$ gene were amplified by Polymerase Chain Reaction (PCR) and sequenced. A total of three SNPs were identified in this study, all of them located in exon 5 (rs527023314, rs 722016629 , and rs 134387246), the latter one positioned in the stop codon. All three SNPs identified in exon 5 characterized synonymous mutations. Only SNP rs134387246 exhibited a significant value $(\mathrm{P} \leq 0.10)$ for EPO and AFC. The association study of SNP rs134387246 revealed an over-dominance effect $(\mathrm{P}=0.056)$, and no additive effect was observed $(\mathrm{P}=0.67)$. A reduction of 2.5 months $(75$ days $)$ in the age at first calving of heterozygous heifers for the SNP rs134387246 was observed. For the first time, polymorphisms of the $A M H$ gene were described in Nelore heifers and associated with sexual precocity traits.
\end{abstract}

Key words: Age at first calving. Bos taurus indicus. Early pregnancy occurrence. Fertility. SNP.

\footnotetext{
1 Discente, Curso de Mestrado do Programa de Pós-Graduação em Medicina Veterinária, Departamento de Medicina Veterinária Preventiva e Reprodução Animal, Faculdade de Ciências Agrárias e Veterinárias, UNESP, Jaboticabal, SP, Brasil. E-mail: juliacpierucci@hotmail.com

2 Profs., Departamento de Zootecnia, Faculdade de Ciências Agrárias e Veterinárias, FCAV-UNESP, Jaboticabal, SP, Brasil. E-mail: tonhati@fcav.unesp.br; lgalb@fcav.unesp.br

3 Discentes, Pós-Doutorado, Departamento de Zootecnia, Faculdade de Ciências Agrárias e Veterinárias, UNESP, Jaboticabal, SP, Brasil.E-mail: diercles.cardoso@yahoo.com.br; daniel_jordan2008@hotmail.com; camila_urbano@yahoo.com.br

${ }^{4}$ Discente, Curso de Doutorado do Programa de Pós-Graduação em Melhoramento Animal, Departamento de Zootecnia, Faculdade de Ciências Agrárias e Veterinárias, UNESP, Jaboticabal, SP, Brasil. E-mail: anafreitas.zoo7@yahoo.com.br

5 Prof., Universidade Federal Rural do Rio de Janeiro, UFRRJ, Rio de Janeiro, RJ, Brasil. E-mail: marina.mortati@gmail.com

${ }_{6}$ Prof., Departamento de Zootecnia, Universidade Federal da Bahia, UFBA, Salvador, BA, Brasil. E-mail: gregoriocamargo@ hotmail.com

7 Prof., Departamento de Medicina Veterinária Preventiva e Reprodução Animal, Faculdade de Ciências Agrárias e Veterinárias, UNESP, Jaboticabal, SP, Brasil. E-mail: gimeneslu@fcav.unesp.br

* Author for correspondence
} 


\section{Resumo}

O hormônio Anti-Mülleriano (AMH) é uma proteína expressa nas gônadas e está relacionada ao desenvolvimento folicular ovariano. O objetivo desse trabalho foi investigar a presença de polimorfismos do gene $A M H$ em um rebanho Nelore, analisar a constituição genética da população para o gene e estudar a associação entre os polimorfismos e as características ocorrência de prenhez precoce (OPP) e idade ao primeiro parto (IPP). Os dados fenotípicos consistiram da verificação da prenhez precoce e idade ao primeiro parto de 197 novilhas, não aparentadas, expostas à estação de monta com idade entre 15 e 17 meses (grupo precoce) ou 24 meses (grupo não precoce). O grupo denominado "precoce" foi composto por 67 novilhas com idade ao primeiro parto de $26.5 \pm 0.59$ meses, e o segundo denominado "não precoce" composto por 130 novilhas com idade ao primeiro parto de $36.4 \pm 0.99$ meses. Os cinco éxons do gene $A M H$ foram amplificados por meio da técnica de Reação em Cadeia da Polimerase (PCR) e sequenciados. Um total de três SNPs foram identificados nesse estudo, todos localizados no éxon 5 (rs527023314, rs722016629 and rs134387246), sendo o último posicionado stop codon. Os três SNPs identificados caracterizaram mutações sinônimas. Somente o SNP rs134387246 exibiu associação significante $(\mathrm{P} \leq 0.10)$ para ambas características (OPP e IPP). O estudo de associação do SNP rs134387246 revelou um efeito de sobre dominância $(\mathrm{P}=0,056)$, e ausência de ação gênica aditiva $(\mathrm{P}=0,67)$. Foi observada redução de 2,5 meses ( 75 dias) na idade ao primeiro parto de novilhas heterozigotas para o SNP rs134387246. Pela primeira vez na literatura, polimorfismos do gene $A M H$ foram descritos em novilhas da raça Nelore e associados a características indicadoras de precocidade sexual.

Palavras-chave: Bos indicus. Fertilidade. Idade ao primeiro parto. Ocorrência de prenhez precoce. SNP.

\section{Introduction}

Reproductive performance has an important economic relevance for cattle husbandry, mainly in zebu herds, which present an inferior reproductive performance, increased age at puberty, and higher age at first calving when compared to taurine breeds (CHENOWETH, 1994). Some of the selection criteria used in breeding programs include indicative traits of sexual precocity in heifers, such as early pregnancy occurrence (ELER et al., 2002) and age at first calving (GRESSLER et al., 2005).

In a genome-wide association study (GWAS) in Nelore cattle, Matos et al. (2014) identified SNP variants, candidate genes, and biological functions potentially associated with age at first calving and gestation period. According to this study, the anti-Müllerian hormone gene $(A M H)$, located at chromosome 7 (BTA7), is a potential candidate involved in the expression of age at first calving. Moreover, AMH has been identified as an important marker of the ovarian reserve (FANCHIN et al., 2003; GRUIJTERS et al., 2003), since this hormone is related to the modulation of early follicular growth, preventing premature exhaustion of the ovarian reserve (DURLINGER et al., 2002a).

The area of reproductive genetics in women has progressively gained a high profile. Polymorphisms located in exons 1 and/or 2 of the $A M H$ gene (as well as in AMHRII receptor) have been associated with granulosa cell number, increased the frequencies of Polycystic Ovarian Syndrome (PELLAT et al., 2010), Ovarian Hyperstimulation Syndrome (ZHAO; ZHANG, 2013), and infertility (PELLAT et al., 2010).

In animals, $\mathrm{AMH}$ serum concentrations are positively correlated with the number of ovarian follicles, e.g., in rodents (DURLINGER et al., 2002b), goats (MONNIAUX et al., 2011), buffaloes (BALDRIGHI et al., 2014), as well as taurine and zebu cattle (IRELAND et al., 2008; RICO et al., 2009; BALDRIGHI et al., 2014). Recently, in Japan, a high AMH serum concentration has been correlated with precocious puberty of heifers (ElSHEIKH ALI et al., 2017). Furthermore, in cattle, 
AMH was related to either in vivo and in vitro embryo production (TAKAHASHI et al., 2008; RICO et al., 2009; GUERREIRO et al., 2014), the occurrence of theca-granulosa cell tumors (ElSHEIKH ALI et al., 2013), reproductive longevity in females (JIMENEZ-KRASSEL et al., 2014), differences in pregnancy rates, and pregnancy loss between 30 and 45 days of gestation (JIMENEZKRASSEL et al., 2014; RIBEIRO et al., 2014). However, the origin of the alterations in circulating concentrations of AMH is unclear. Although AMH can be used mainly as a marker of the follicular pool, the effects of polymorphisms in the genes that encode both $A M H$ and its receptor are still unknown, especially regarding other reproductive features.

Considering the existence of polymorphism in the $A M H$ gene in humans, related to reproductive functions, and the low number of studies of polymorphisms in this gene in cattle breeds, the aims of this study on Nelore heifers were to: 1) characterize the presence of polymorphisms in the $A M H$ gene; 2) analyze the genetic constitution of the population for the gene, and 3) associate polymorphisms with early pregnancy occurrence (EPO) and age at first calving (AFC).

\section{Material and Methods}

\section{Animals}

This study was approved by the Ethics Committee on Animal Experimentation (CEUA) of the Faculdade de Ciências Agrárias e Veterinárias, Unesp Jaboticabal (protocol nº17958/15).

Phenotypic information and biological material of 197 Nelore heifers from Agropecuária Jacarezinho LTDA (Cotegipe, Bahia, Brazil) were used in the study. All heifers in the herd, aged between 15 and 17 months, were exposed to artificial insemination or natural mating with a single sire or multiple sires (sire: heifer ratio of 1: 32), regardless of weight and body condition, and this first breeding season lasted approximately 70 days, between February and
April. Pregnancy diagnosis was performed by rectal palpation approximately 60 days after the end of the breeding season. Heifers that did not conceive in the breeding season at 15 to 17 months were once again exposed to artificial insemination or natural mating with a single sire or multiple sires (sire: heifer ratio of 1: 32) at the age of approximately 24 months, between November and December (second breeding season; 60 days of duration), with pregnancy diagnosis being performed 60 days after the end of the breeding season. Heifers with another negative performance (second breeding season) were culled.

Retrospectively, two groups of animals were established: the first group was composed of 67 heifers confirmed pregnant in the first breeding season and with an age at first calving of $796 \pm$ 17.8 days (26.5 \pm 0.59 months), the so-called “ precocious group"; the second group consisted of 130 heifers diagnosed pregnant in the second breeding season and with an age at first calving of 1,092 \pm 29.9 days (36.4 \pm 0.99 months), the socalled "non-precocious group".

\section{DNA extraction}

The DNA analyses were performed at the Laboratory of Molecular Genetics of the Department of Animal Science, São Paulo State University (Unesp), Jaboticabal-SP, Brazil.

Briefly, DNA was extracted from hair follicle samples using the phenolchloroform-isoamyl alcohol method (SAMBROOK; FRITSCH; MANIATIS, 1989).

\section{Primer design and DNA amplification by PCR} (Polymerase Chain Reaction)

Five primer pairs were designed, specific for each exon of the $A M H$ gene (Bos taurus sequence; Genbank accession No. NC_007305.6), as shown in Table 1. The primers were obtained using the Primer3 software (ROZEN; SKALETSKY, 2000). 
Table 1. Primers used for $A M H$ gene amplification, amplicon size of each primer pair, amplified region of the AMH gene, and annealing temperature of the primers.

\begin{tabular}{lccc}
\hline \multicolumn{1}{c}{ Primer } & Amplicon size (bp) & Amplified region & Annealing temperature \\
\hline $\begin{array}{l}\text { F: 5' GTTGGAACAGAAGGGGCTTT 3' } \\
\text { R: 5' AGACTGGGGAGGGGTCTG 3' }\end{array}$ & 714 & Exon 1 & $63.0^{\circ} \mathrm{C}$ \\
F: 5' CCACTGTCCTCAGACCCACT 3' & & & \\
R: 5' GATGCCAACCCTGCTCTG 3' & 603 & Exon 2 & $55.7^{\circ} \mathrm{C}$ \\
F: 5' GGGATTATGGGTTTGGGTT 3' & & & \\
R: 5' CGTGAGAGTCTCCAGGAAGG 3' & 683 & Exons 3-4 & $57.0^{\circ} \mathrm{C}$ \\
F: 5' GCCCTTCCCGCAGCCCAG 3' & & & \\
R: 5' GCCGCTCCGCTCCCGCC 3' & 613 & Exon 5 (partial) & $68.0^{\circ} \mathrm{C}$ \\
F: 5' GCTGCTGCTGCTCAAAGC 3' & & & \\
R: 5' GCAAGGCAACAGGTGAAGAC 3' & 574 & Exon 5 (partial) & $60.4^{\circ} \mathrm{C}$ \\
\hline
\end{tabular}

The exon regions of the $A M H$ gene were amplified by PCR (Polymerase Chain Reaction) in a final volume of $30 \mu \mathrm{L}$ reaction mixture, containing $4 \mu \mathrm{L}$ of DNA (105 ng), $3 \mu \mathrm{L}$ of each primer (15 pM), $13 \mu \mathrm{L}$ of $\mathrm{GoTaq}^{\circledR}$ Colorless Master Mix (Promega, USA), and $7 \mu \mathrm{L}$ of nuclease-free water.

The amplification reaction was performed using a thermocycler (Master Cycler Gradient 5331; Eppendorf ${ }^{\circledR}$, Germany) and consisted of the following steps: initial denaturation at $95^{\circ} \mathrm{C}$ for $5 \mathrm{~min}$, followed by 34 cycles of denaturation at $95^{\circ} \mathrm{C}$ for $1 \mathrm{~min}$, annealing reaction (following the specific temperature to each primer pair; Table 1) for $1 \mathrm{~min}$, and extension at $72^{\circ} \mathrm{C}$ for $1 \mathrm{~min}$. The final extension step was performed at $72^{\circ} \mathrm{C}$ for 5 min. After PCR amplification, $2 \mu \mathrm{L}$ of each sample were electrophoresed on agarose gel (1.5\%) stained with GelRed ${ }^{\mathrm{TM}}$ (Biotium, USA) in 1X TBE buffer (Tris- $89 \mathrm{mM} \mathrm{HCl}, 2.5 \mathrm{mM}$ EDTA, $89 \mathrm{mM}$ Boric Acid; $\mathrm{pH} 8.3$ ) at $90 \mathrm{~V}$ for approximately 50 minutes. Visualization of the amplified DNA was performed using ultraviolet (UV) light, and the gel was photographed with a Gel-Doc ${ }^{\mathrm{TM}}$ apparatus (BioRad, USA). The images were analyzed with the Image Analysis software (Kodak, USA) to evaluate the amplification efficiency. The PCR products were stored at $-20^{\circ} \mathrm{C}$ until purification was performed.
Sequencing and genotyping

The PCR products were purified following the protocol recommended for the Wizard ${ }^{\circledR}$ SV Gel, using the PCR Clean-Up System kit (Promega, USA).

The samples were sequenced for both primers (forward and reverse) by the dideoxyribonucleoside triphosphate chain termination method (ddNTP), using the ABI PRISM Big Dye Terminator Cycle Sequencing Ready Reaction Kit (Applied Biosystems) in an ABI 3730 XLautomatic sequencer (Applied Biosystems, USA). For polymorphisms identification, the obtained DNA sequences were visualized and analyzed by the CodonCode Aligner version 5.1.5 program (CodonCode Corporation, Dedham, MA, USA), available online at http:// www.codoncode.com/aligner/download.htm.

\section{Statistical analysis}

Allelic and genotypic frequencies

Allelic and genotypic frequencies of the SNPs were calculated by allele counting to verify whether the genotyped population was in Hardy-Weinberg equilibrium. Possible deviations of both allele and genotype frequencies were tested using the Chisquare test (FALCONER; MACKAY, 1996). 


\section{Linkage disequilibrium}

Linkage disequilibrium (LD) was estimated through regression analysis (HILL; ROBERTSON, 1968), using the Plink computational software (PURCELL et al., 2007) to verify which SNPs segregated together. Values of $\mathrm{r}^{2}$ greater than 0.33 were considered a high LD (ARDLIE et al., 2002).

Considering two loci with two alleles for each locus $\left(\mathrm{A}_{1} / \mathrm{A}_{2}\right.$ and $\left.\mathrm{B}_{1} / \mathrm{B}_{2}\right)$, we have:

$$
r^{2}=\frac{\left(\text { freq. }\left(A_{1} B_{1}\right) \times \text { freq. }\left(A_{2} B_{2}\right)-\text { freq. }\left(A_{1} B_{2}\right) \times \text { freq. }\left(A_{2} B_{1}\right)\right)^{2}}{\text { freq. }\left(A_{1}\right) \times \text { freq. }\left(A_{2}\right) \times \text { freq. }\left(B_{1}\right) \times \text { freq. }\left(B_{2}\right)}
$$

Where: freq. $A_{1}$, freq. $A_{2}$, freq. $B_{1}$ and freq. $B_{2}$ are the frequencies of alleles $A_{1}, A_{2}, B_{1}$ and $B_{2}$, respectively (HILL, 1981).

\section{Association analysis}

Phenotypic records consisted of the verification of conception. The EPO was defined based on the conception and calving of the heifer, since they had entered the mating season at an age of 15 to 17 months. The EPO is a binary variable, that is, heifers that calved at less than 31 months (meaning that they were pregnant at the age of 15 to 17 months) were assigned the value 1 (success), and those that failed received the value 0 (failure) (SILVA et al., 2005). The AFC, measured in days, was obtained by the difference between the date of the first calving and the date of birth of the heifer. For females that failed at the first breeding season, the AFC of the second exposure was considered at 24 months.

Associations between the SNPs and phenotypic records were analyzed using the GLIMMIX procedure of SAS 9.3® (Statistical Analysis Software, SAS Institute Inc., Cary, NC, USA, 2011). Only SNPs that had a minor allele frequency (MAF) higher than 5\% were kept for association studies to avoid compromising the ability to identify true associations correlated with the trait of interest (ZIEGLER et al., 2008). For EPO analysis, a binomial distribution with a logistic link function was used, while for AFC, a normal distribution was used.
The effect of the genotypes identified for the $A M H$ gene on EPO and AFC was calculated, and the fixed effects of contemporary group (CG) and genotype of each polymorphism and the random effect of the sire were included in the statistical model. The CGs were defined as animals from the same farm, year, and season of birth. For CG analysis, 208 animals were initially included; CGs with less than three animals were eliminated from the analysis, resulting in 197 animals. When the genotype effects were significant according to the Fisher test $(\mathrm{P} \leq 0.1)$, the averages between the genotypes were compared by Tukey's test. Additionally, the additive and dominance effects of the significant SNPs were tested, maintaining the same significance level. Therefore, the same model was used to verify the additive and dominance effects, considering the marker effect as covariate. To verify the additive effect, the genotypes were coded in 0,1 , or 2 , according to the number of copies of the lower frequency allele, while for the dominance effect, the homozygotes were coded in 0 and the heterozygotes in 1 .

\section{Results and Discussion}

Three SNPs were identified in 20 animals of the initial sample, all of them located in exon 5 (rs527023314, C > T; rs722016629, G > A, and rs134387246, G > A; Table 2). 
Table 2. Identified polymorphisms in 197 Nelore heifers: Minor Frequency Allele (MAF), chromosome position, and region of the gene, nucleotide alteration, and consequence of the mutation.

\begin{tabular}{ccccccc}
\hline Chr & Genomic Position* & Region & SNP $^{\mathrm{a}}$ & Alteration & Consequence & MAF \\
\hline 7 & 22699121 & Exon5 & rs527023314 & C $>$ T & Synonymous & 0.378 \\
7 & 22699264 & Exon5 & rs722016629 & G $>$ A & Synonymous & 0.010 \\
7 & 22699764 & Exon5 (stop codon) & rs134387246 & G $>$ A & Synonymous & 0.317 \\
\hline
\end{tabular}

aPolymorphism represented as the reference SNP ID number (rs) provided by the SNP database in the NCBI (accession number NC_007305.6); Chr represents the Bos taurus autosome (Bta)

*Genomic position according to UMD3.1 assembly.

Allelic and genotypic frequencies as well as $\mathrm{P}$ values for the Hardy-Weinberg equilibrium test for the 197 sequenced animals are shown in Table 3. The calculations of allelic and genotypic frequencies were performed to study whether the constitution and genetic diversity of a population, and the Hardy-Weinberg equilibrium, established a model for the behavior of genes and can be used to analyze whether there was an effect of migration, mutation, and selection on the studied population (SALMAN, 2007). All the SNPs identified were in Hardy-Weinberg equilibrium, indicating that these loci are probably not affected by selection.

Table 3. Allelic and genotypic frequencies and Hardy-Weinberg Equilibrium for the three SNPs identified in the $A M H$ gene of 197 Nelore heifers.

\begin{tabular}{ccccccc}
\hline Polymorphisms $^{\mathrm{a}}$ & \multicolumn{2}{c}{ Allelic Frequency } & \multicolumn{3}{c}{ Genotypic Frequency $^{\text {P value }(\mathrm{H}-\mathrm{W})^{\mathrm{b}}}$} \\
\hline \multirow{2}{*}{ rs527023314 } & $\mathrm{C}$ & $\mathrm{T}$ & $\mathrm{CC}$ & $\mathrm{CT}$ & $\mathrm{TT}$ & 0.288 \\
& $62 \%$ & $38 \%$ & $41 \%$ & $43 \%$ & $16 \%$ & \\
rs722016629 & $\mathrm{G}$ & $\mathrm{A}$ & $\mathrm{GG}$ & $\mathrm{GA}$ & $\mathrm{AA}$ & 1 \\
& $99 \%$ & $1 \%$ & $98 \%$ & $2 \%$ & $0 \%$ & \\
rs134387246 & $\mathrm{G}$ & $\mathrm{A}$ & $\mathrm{GG}$ & $\mathrm{GA}$ & $\mathrm{AA}$ & \multirow{2}{*}{0.187} \\
& $68 \%$ & $32 \%$ & $49 \%$ & $39 \%$ & $12 \%$ & \\
\hline
\end{tabular}

aPolymorphism represented as reference SNP ID number $(r s)$ provided by NCBI dbSNP

${ }^{\mathrm{b}}$ Chi-square test at 5\% significance level.;H-Wis the Hardy-Weinberg Equilibrium

The linkage disequilibrium (LD) consists of the correlation of genotypes between genetic markers and can be used to quantify effects that may affect linkage between SNPs, such as frequency and recombination between markers, recurrent mutations, and population history. The LD can indicate whether polymorphisms are more frequently inherited together or not (HARTL; CLARK, 1997). In the present study, LD analysis demonstrated independent segregation of exon 5 SNPs, despite the short distance across loci (Table 4).

Table 4. Estimates of $\mathrm{r}^{2}$ values for the three SNPs (rs527023314, rs722016629, and rs134387246) found in the $A M H$ gene of 197 Nelore heifers.

\begin{tabular}{cccc}
\hline SNP & rs527023314 & rs722016629 & rs134387246 \\
\hline rs527023314 & - & 0.00991962 & 0.0402859 \\
rs722016629 & & - & 0.0007886 \\
rs134387246 & & & - \\
\hline
\end{tabular}


All three SNPs identified in exon 5 characterized synonymous mutations, which means they do not lead to amino acid substitution in the protein. The SNPs rs527023314 and rs722016629 are located in exon regions encoding the amino acids leucine and proline, respectively, and the third SNP (rs134387246) is situated in a stop codon region (Table 2).

"Silent mutations" or "synonymous nucleotide substitutions" do not promote any changes in the encoded amino acid nor in its sequence (FORTES et al., 2014). However, several studies have discussed that silent mutations can alter transcription rates, thus affecting protein levels (FLINT; WOOLLIAMS, 2008) and messenger RNA stability (CAPON et al., 2004). Therefore, despite the fact that the SNPs identified in the present study were characterized as silent mutations, it is possible that they may alter $A M H$ gene expression, affecting the concentrations of proteins and, in turn, leading to phenotypic changes in Nelore females.

The SNP rs722016629 was excluded from the association analysis since it presented an MAF less than 0.05. Association analysis between the other two SNPs (rs527023314 and rs134387246) and EPO and AFC, individually, demonstrated that only rs134387246, located at the stop codon, shows an association for both traits at $10 \%$ level of significance (Table 5). The AFC values of genotypes of this SNP (rs134387246) are presented in Table 6. It is likely that the increase in the number of animals may reinforce the significance of the SNP aforementioned. Thus, this SNP should be further studied in future experiments with larger numbers of animals. The heterozygous individuals showed a shorter AFC (75 days; Table 6) compared to the average AFC of the homozygotes, representing over-dominance.

Table 5. P values (F-test) of the SNPs identified for early pregnancy occurrence (EPO) and age at first calving (AFC) in 197 Nelore heifers.

\begin{tabular}{ccc}
\hline \multirow{2}{*}{ SNP $^{\mathrm{a}}$} & \multicolumn{2}{c}{ Traits } \\
\cline { 2 - 3 } & EPO & AFC \\
\hline rs134387246 & 0.059 & 0.060 \\
rs527023314 & 0.239 & 0.283 \\
\hline
\end{tabular}

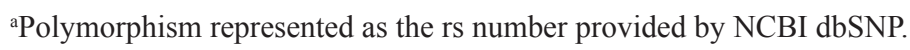

Table 6. Number of animals (N), mean and standard error (SD) of the characteristic age at first calving (AFC; days) according to the genotypes (AA, GA, and GG) of the SNP rs134387246.

\begin{tabular}{ccc}
\hline Genotypes & N & AFC (days) \pm SD \\
\hline AA & 24 & $1.004 \pm 21,59^{\mathrm{ab}}$ \\
GA & 75 & $972,72 \pm 31,76^{\mathrm{a}}$ \\
GG & 96 & $1.047,73^{\mathrm{b}}$ \\
\hline
\end{tabular}

${ }^{\mathrm{ab}}$ Means within a row with different superscripts are significantly different (Tukey's test; $\mathrm{P} \leq 0.05$ ).

The mechanism of action of SNP rs134387246 revealed an over-dominance effect of the heterozygote $(p=0.05$; Table 6$)$, and an additive effect was not observed $(\mathrm{p}=0.67)$.
Different types of gene interaction, defined as non-additive genetic variance such as dominance, over-dominance, and epistasis, are related to the expression of heterosis, which is explained by 
increased progeny heterozygous (MOURÃO et al., 2008). Heterosis refers to the average of the paternal lineages, indicating any deviation of the additivity observed in genetically distinct populations in relation to its origin, with its intensity being directly proportional to the genetic distance between the breeds or lineages (TEODORO et al., 2001). This phenomenon is important in several features of economic interest, particularly those with low heritability, such as the ones related to adaptation and reproductive traits (ROSO; FRIES, 2000). Heterosis is also evidenced in inbred or purebred population progeny (KOURY FILHO, 2002).

Although no mating was performed in the present study to explore heterosis, the over-dominance identified could contribute to the occurrence of this event, and it is a genetic tool to improve production performance.

The SNP rs134387246 causes a substitution of guanine for adenine in the stop codon. This nucleotide change did not cause an alteration in the protein, but suggested some reduction of the age at first calving of Nelore heifers. Functional studies, with a larger population, are needed to better comprehend the mechanism of the SNP. According to the presented data (Table 6), there is a decrease of 2.5 months (75 days) for age at first calving in heterozygous animals for this SNP. This data is of relevant importance because animals with this genotype conceive in the beginning of the breeding season, which means that they can be maintained in the herd in the following season.

The EPO and AFC are complex features and influenced by numerous environmental (CAMPELLO et al., 1999) and genetic factors (GROSSI et al., 2009). Direct selection for sexual precocity in heifers is complicated by the complexity to identify the onset of puberty. According to Meirelles et al. (2009), the use of indicators of sexual precocity, such as EPO, which is easily measured, is a good alternative to overcome this problem.
In this study, polymorphisms of the $A M H$ gene described in Nelore heifers for the first time and associated with reproductive traits, wherein an SNP demonstrated a positive influence and could be further used as a tool to improve beef cattle production performance.

\section{Conclusions}

In the present study, three polymorphisms located in exon 5 of the $A M H$ gene were characterized in a Nelore population. An SNP was significantly associated to EPO and AFC, and an over-dominance effect of an SNP was identified for AFC. In the future, this can be used to improve beef cattle production performance. Further studies are needed to analyze the implications of polymorphisms on reproductive performance in a larger population.

\section{Acknowledgments}

This work was supported by $\mathrm{CNPq}$ and Fapesp (Grant no. 2009/16118-5). We would like to thank Agropecuária Jacarezinho LTDA for providing the database for the experiment.

\section{References}

ARDLIE, K. G.; KRUGLYAK, L.; SEIELSTAD, M. Patterns of linkage disequilibrium in the human genome. Nature Reviews, London, v. 3, n. 4, p. 299-309, 2002.

BALDRIGHI, J. M.; SÁFILHO, M. F.; BATISTA, E. O. S.; LOPES, R. N. V. R.; VISINTIN, J. A.; BARUSELLI, P. S.; ASSUMPÇÃO, M. E. O. A. Anti-mullerian hormone concentration and antral ovarian follicle population in murrah heifers compared to holstein and gyr kept under the same management. Reproduction in Domestic Animals, Linköping, v. 49, n. 6, p. 1015-1020, 2014. DOI: $10.1111 /$ rda. 12430

CAMPELLO, C. C.; MARTINS FILHO, R.; LOBO, R. N. B. Intervalo de partos e fertilidade real em vacas Nelore no Estado do Maranhão. Revista Brasileira de Zootecnia, Viçosa, MG, v. 28, n. 3, p. 474-479, 1999.

CAPON, F.; ALLEN, M. H.; AMEEN, M.; BURDEN, A. D.; TILLMAN, D.; BARKER, J. N.; TREMBATH, R. C. 
A synonymous SNP of the corneodesmosin gene leads to increased mRNA stability and demonstrates association with psoriasis across diverse ethnic groups. Human Molecular Genetics, Oxford, v. 13, n. 20, p. 2361-2368, 2004. DOI: $10.1093 / \mathrm{hmg} / \mathrm{ddh} 273$

CHENOWETH, P. J. Aspects of reproduction in female Bos indicus cattle: a review. Australian Veterinary Journal, Sydney, v. 71, n. 12, p. 422-428, 1994. DOI: 10.1111/j.1751-0813.1994.tb00961.x

DURLINGER, A. L. L.; GRUIJTERS, M. G. J.; KRAMER, P.; KARELS, B.; INGRAHAM, H. A.; NACHTIGAL, M. W.; UILENBROEK, J. T. J.; GROOTEGOED, J. A.; THEMMEN, A. P. N. AntiMüllerian hormone inhibits initiation of primordial follicle growth in the mouse ovary. Endocrinology, Oxford, v. 143, n. 3, p. 1076-1084, 2002b. DOI: 10.1210/ endo.143.3.8691

DURLINGER, A. L. L.; VISSER, J. A.; THEMMEN, A. P. N. Regulation of ovarian function: the role of antiMüllerian hormone. Reproduction, Montreal, v. 124, n. 5, p. 601-609, 2002a.

ELER, J. P.; SILVA, J. A.; FERRAZ, J. B.; DIAS, F.; OLIVEIRA, H. N.; EVANS, J. L.; GOLDEN, B. L. Genetic evaluation of the probability of pregnancy at 14 months for Nelore heifers. Journal of Animal Science, Oxford, v. 80, n. 8, p. 951-954, 2002. DOI: $10.2527 / 2002.804951 \mathrm{x}$

EL-SHEIKH ALI, H.; KITAHARA, G.; NIBE, K.; YAMAGUCHI, R.; HORII, Y.; ZAABEL, S.; OSAWA, T. Plasma anti-Müllerian hormone as a biomarker for bovine granulosa-theca cell tumors: comparison with immnoreactive inhibin and ovarian steroid concentrations. Theriogenology, New York, v. 80, n. 8, p. 940-949, 2013. DOI: $10.1016 / j$.theriogenology.2013.07.022

EL-SHEIKH ALI, H.; KITAHARA, G.; TAKAHASHI, T.; MIDO, S.; SADAWY, M.; KOBAYASHI, I.; HEMMI, K.; OSAWA, T. Plasma Anti-Müllerian hormone profile in heifers from birth through puberty and relationship with puberty onset. Biology of Reproduction, Oxford, v. 97, n. 1, p. 153-160, 2017.

FALCONER, D. S.; MACKAY, T. F. C. Introduction to quantitative genetics. $4^{\text {th }}$ ed. New York: Longman, 1996. $480 \mathrm{p}$.

FANCHIN, R.; SCHONEAUER, L. M.; RIGHINI, C.; GUIBOURDENCHE, J.; FRYDMAN, R.; TAIEB, J. Serum anti-Müllerian hormone is more strongly related to ovarian follicular status than serum inhibin B, estradiol, FSH and LH on day 3. Human Reproduction, Oxford, v. 18, n. 2, p. 323-327, 2003. DOI: 10.1093/humrep/deg042
FLINT, A. P. F.; WOOLLIAMS, J. A. Precision animal breeding. Philosophical transactions of the Royal Society of London. Journal of Biological Sciences, Faisalabad, v. 363, n. 1491, p. 573-590, 2008.

FORTES, M. R.; PORTO-NET, L. R.; DEATLE, K. L.; REVERTE, A.; THOMAS, M. G.; MOOR, S. S.; LEHNER, S. A.; SNELLIN, W. M. Genetic markers in transcription factors of differentially expressed genes associated with post-partum anoestrus predict pregnancy outcome in an independent population of beef cattle. In: WORLD CONGRESS OF GENETICS APPLIED TO LIVESTOCK PRODUCTION, 10, 2014, Vancouver. Proceedings...Vancouver: American Society of Animal Science, 2014. p. 250.

GRESSLER, M. G. M.; PEREIRA, J. C. C.; BERGMANN, J. A. G.; ANDRADE, V. J.; PAULINO, M. F.; GRESSLER, S. L. Aspectos genéticos do peso à desmama e de algumas características reprodutivas de fêmeas Nelore. Arquivo Brasileiro de Medicina Veterinária e Zootecnia, Belo Horizonte, v. 57, n. 4, p. 533538, 2005. DOI: 10.1590/S0102-09352005000400015

GROSSI, D. A.; VENTURINI, G. C.; DE PAZ, C. C. P.; BEZERRA, L. A. F.; LÔBO, R. B.; OLIVEIRA, J. A.; MUNARI, D. Genetic associations between age at first calving and heifer body weight and scrotal circumference in Nelore cattle. Journal of Animal Breeding and Genetics, Berlin, v. 126, n. 5, p. 387-393, 2009. DOI: 10.1111/j.1439-0388.2008.00791.x

GRUIJTERS, M. J.; VISSER, J. A.; DURLINGER, A. L.; THEMMEN, A. P. Anti-Müllerian hormone and its role in ovarian function. Molecular and Cellular Endocrinology, Limerick, v. 211, n. 1-2, p. 85-90, 2003. DOI: 10.1016/j.mce.2003.09.024

GUERREIRO, B. M.; BATISTA, E. O. S.; VIEIRA, L. M.; SÁ FILHO, M. F.; RODRIGUES, C. A.; CASTRO NETTO, A.; SILVEIRA, C. R. A.; BAYEUX, B. M.; DIAS, E. A. R.; MONTEIRO, F. M.; ACCORSI, M.; LOPES, R. N. V. R.; BARUSELLI, P. S. Plasma Anti-Müllerian hormone: an endocrine marker for in vitro embryo production from Bos taurus and Bos indicus donors. Domestic Animal Endocrinology, Auburn, v. 49, n. 1, p. 96-104, 2014. DOI: 10.1016/j. domaniend.2014.07.002

HARTL, D. L.; CLARK, A. G. Principles of population genetics. 3rd ed. Sunderland, MA, USA: Sinauer Assoc., $1997.635 \mathrm{p}$.

HILL, W. G.; ROBERTSON, A. Linkage disequilibrium in finite populations. Theoretical and Applied Genetics, Berlin, v. 38 , n. 6 , p. $226-231$, 1968. DOI: $10.1007 /$ BF01245622 
HILL, W.G. Estimation of effective population size from data on linkage disequilibrium. Genetic Research, Cambridge 38, n. 3, p. 209-216, 1981.

IRELAND, J. L.; SCHEETZ, D.; JIMENEZ-KRASSEL, F.; THEMMEN, A. P.; WARD, F.; LONERGAN, P.; SMITH, G. W.; PEREZ, G. I.; EVANS, A. C.; IRELAND, J. J. Antral follicle count reliably predicts number of morphologically healthy oocytes and follicles in ovaries of young adult cattle. Biology of Reproduction, Oxford, v. 79, n. 6, p. 1219-1225, 2008. DOI: 10.1095/ biolreprod.108.071670

JIMENEZ-KRASSEL, F.; SCHEETZ, D. M.; NEUDER, L. M.; IRELAND, J. L. H.; PURSLEY, J. R.; SMITH, G. W.; IRELAND, J. J. Concentration of anti-Müllerian hormone in dairy heifers is positively associated with productive herd life. Journal of Dairy Science, Champaign, v. 98 , n. 5, p. 3036-3045, 2014. DOI: 10.3168/jds.2014-8130

KOURY FILHO, W. Mitos e realidade sobre consanguinidade ou endogamia. Revista $A B C Z$, Uberaba, n. 2 , v. 10 , p. $1-5,2002$. Available at: http://www. brasilcomz.com/enviados/201573133514.pdf. Acessed at: 24 jan. 2017.

MATOS, M. C.; UTSUNOMIYA, Y. T.; SENO, L. O.; NELLORE, B.; GARCIA, J. F. Associação genômica ampla para idade ao primeiro parto em bovinos Nelore. In: CONGRESSO BRASILEIRO DE RECURSOS GENÉTICOS, 3., 2014, Brasília. Anais... Brasília: Sociedade Brasileira de Recursos Genéticos, 2014. p. 1.

MEIRELLES, S. L.; ESPASANDIN, A. C.; MATTAR, M.; QUEIROZ, S. A. Efeitos genéticos e ambientais sobre características de precocidade sexual em bovinos Nelore. Revista Brasileira de Zootecnia, Viçosa, MG, v. 38, n. 8, p. 1488-1493, 2009.

MONNIAUX, D.; BARIL, G.; LAINE, A. L.; JARRIER, P.; POULIN, N.; COGNIÉ, J.; FABRE, S. Anti-Müllerian Hormone as a predictive endocrine marker for embryo production in the goat. Reproduction, Montreal, v. 142, n. 6, p. 845-854, 2011. DOI: 10.1530/REP-11-0211

MOURÃO, G. B.; FERRAZ, J. B. S.; ELER, J. P.; BUENO, R. S.; BALIEIRO, J. C. C.; MATTOS, E. C.; FIGUEIREDO, L. G. G. Non additive genetic effects on weights and performance of a Brazilian Bos taurus x Bos indicus beef composite. Genetics and Molecular Research, Ribeirão Preto, v. 7, n. 4, p. 1156-1163, 2008. DOI: $10.4238 /$ vol7-4gmr501

PELLAT, L.; RICE, S.; MASON, H. D. Anti-Müllerian hormone and polycystic ovary syndrome: a mountain too high? Reproduction, Montreal, v. 139, n. 5, p. 825-833, 2010. DOI: $10.1530 /$ REP-09-0415
PURCELL， S.; NEALE，B.; TODD-BROWN，K.; THOMAS, L.; FERREIRA, M. A.; BENDER, D.; MALLER, J.; SKLAR, P.; DE BAKKER, P. I.; DALY, M. J.; SHAM, P. C. PLINK: a tool set for whole-genome association and population- based linkage analyses. American Journal of Human Genetics, Birmingham, v. 81, n. 3, p. 559- 575, 2007. DOI: $10.1086 / 519795$

RIBEIRO, E. S.; BISINOTTO, R. S.; LIMA, F. F.; GRECO, L. F.; MORRISON, A.; KUMAR, A. W. W.; THATCHER, W. W.; SANTOS, J. E. P. Plasma antiMüllerian hormone in adult dairy cows and associations with fertility. Journal of Dairy Science, Champaign, v. 97 , n. 11, p. $6888-6900,2014$. DOI: $10.3168 /$ jds.20147908

RICO, C.; FABRE, S.; MEDIGUE, C.; CLEMENTE, N. D.; CLEMENT, F.; BONTOUX, M.; TOUZE, J. L.; DUPONT, M.; BRIANT, E.; RÉMY, B.; BECKERS, J. F.; MONNIAUX, D. Anti-Müllerian hormone is an endocrine marker of ovarian gonadotropin-responsive follicles and can help to predict superovulatory responses in the cow. Biology of Reproduction, Oxford, v. 80, n. 1, p. 50-59, 2009. DOI: 10.1095/biolreprod.108.072157

ROSO, V. M.; FRIES, L. A. Avaliação das heteroses materna e individual sobre o ganho de peso do nascimento ao desmame em bovinos Angus x Nelore. Revista Brasileira de Zootecnia, Viçosa, MG, v. 29, n. 3, p. 732-737, 2000.

ROZEN, S.; SKALETSKY, H. Primer3 on the WWW for general users and for biologist programmers. Methods in Molecular Biology, Totowa, v. 132, p. 365-386, 2000. DOI: $10.1385 / 1-59259-192-2: 365$

SALMAN, A. K. D. Conceitos básicos de genética de populações. Porto Velho: EMBRAPA, 2007. 28 p.

SAMBROOK, J.; FRITSCH, E. F; MANIATIS, T. Molecular cloning: a laboratory manual - manual for genetic engineering. New York: Cold Spring Harbor, 1989. $1546 \mathrm{p}$.

SILVA, J. A. V.; DIAS, L. T.; ALBUQUERQUE, L. G. Estudo genético da precocidade sexual de novilhas em um rebanho Nelore. Revista Brasileira de Zootecnia, Viçosa, MG, v. 34, n. 5, p. 1568-1572, 2005. DOI: 10.1590/S1516-35982005000500017

TAKAHASHI, C.; FUJITO, A.; KAZUDA, M.; SUGIYAMA, R.; ITO, H.; ISAKA, K. Anti- Müllerian hormone substance from follicular fluid is positively associated with success in oocyte fertilization during in vitro fertilization. Fertility and Sterility, New York, v. 89, n. 3, p. 586-591, 2008. DOI: /10.1016/j. fertnstert.2007.03.080 
TEODORO, R. L.; MADALENA, F. E.; LEMOS, A. M.; VERNEQUE, R. S.; MARTINEZ, M. Cruzamento tríplice de raças leiteiras: avaliação de cruzamento de Jersey e Pardo-Suíço com vacas Girolando. Informe Agropecuário, Belo Horizonte, v. 22, n. 211, p. 49-56, 2001.

ZHAO, Y. Q.; ZHANG, H. W. Association of genetic polymorphisms of anti-Müllerian hormone $(A M H)$ and its type II receptor with Ovarian Hyperstimulation Syndrome. Journal of Reproduction and Contraception, Shangai, v. 24, n. 1, p. 30-37, 2013. DOI: 10.1016/S10017844(13)60018-8

ZIEGLER, A.; KÖNIG, I.; THOMPSON, J. Biostatistical aspects of genome wide association studies. Biometrical Journal, Weinheim, v. 50, n. 1, p. 8-28, 2008. DOI: 10.1002/bimj.200710398 
